neral Processing Congress, Vol. I, p. 33 42)

6) Э. В. УТЕУШ. 3. В. УТЕУШ: Влияние некоторых фактэров на режии радоты мальниц (Известия ВУЗ, Цветная Металлурчия, 1966. 3, С. 3 С. 8)

\title{
3307 ジグ槽内に打ける粒子群の挙動
}

\section{1. 緒言}

石炭選別に上める空氮動ジグの比重は極めて大ぎ， 重液選別法の発達した今日に出いても本邦石炭の約 $70 \%$ が空気動ジグにより生産されている。これは選別精度は 重液法に一歩謴るが，処理能力の大きさ，処理可能な粒 度範囲の広さ，操業の容易さ，低廉な操業費など空気動 ジグのもつ優れた性能によるものである。

現代の空気動ジグは機体精造, 空気バルブの進歩拈よ び重産物の排出制御法の発達により，その性能は格段と 向上しているが，荐鉱統合，選孷工場の集約大型化子い う動きは, ジグの処理能力と選別精度をさらに高めると いう課题を提供している。

空気動ジグに関する研究はすでに半世紀の間数多くの 人によつて行なわれ，数々の優れた工業的めるいは実験 室的研究成果が発表されている。しかしその成果を性状 の異なる原炭岁るい恔量の異なるジグへ適用する段階 になると定性的な域を出ず行詰つているのが現状であ る。操業管理も重産物の排出制御は近年フロートに代つ て放射性同位元素をべッドの比重検出に用いる制御機構 の発達によつて著しく向上したが，成層過程における成 層管理については今日な扮何らの自動制御も行なわれて いない。また Mayer, Bird らによつて提案された選別 理論む，いずれも明確な理論として広く認められるに至 つていない。これは、ジグ内に打ける粒子の運動を支配 する要因が極めて多く，粒子の比重別成層の機棈が非常 に複雑なことに原因している。

筆者ら選別を支配する個々の要因效果について基礎 的研究を行ない過去数回にわたり本会にも発表してきた が，これらの研究子個々の要率の働き定性的に示すこ とはできるが，㐫く亦で巽別作用の表面的観察に過ぎ ず，複雑なジグの選別機構を明らかにすることはできな かつた。

このような理由から䇥者らはまずベッドを形成する粒 子群の運動子媒体である水の運動を定量的に測定観察 し, ついで粒子群の運動状態と成層精度との関係を解析 することによつて, 理想的な粒子群の運動状態とそのと きの水の波形を明らか比し, 選別機構の解明と選別過程 自動化の手がかりを得るため研究を開始した。ジダ内に おける単体粒子㐫るいは粒子群全体の動きを捉劣ること はも导かしく，测定方法に今後研究，改良すべき点を多 く残しているが，いるいるなジグ・サイクルに拈ける粒 子群の運動状態とそれにともなう諸現象について測定し た結果をここに報告する。

\section{2. 実験装置および測定法}

第 1 図儿実験装置を示す。試験機任透明樹脂製U字管 型のもので, 選別室の犬きさ $100 \times 100 \times 300($ 高さ) $\mathrm{mm}$, 実測固有振動数は $38.2 \mathrm{cycle} / \mathrm{min}$ である。

本研究のため試作した空気バルブはジニフリー型のる

$\begin{array}{llll}\text { 資源技術試䍄所選炭部第 } 1 \text { 課 } & \text { 高 } & \text { 村 } & \text { 啓 (正会員) } \\ \text { 資源技術試験所選炭部第 } 1 \text { 課 } & \text { 龟 } & \text { 谷 } & \text { 宏 }\end{array}$

ので第2図に望気バルブのポート・ダイヤグラムを示 す。広範用のエヤ・サイクル調整ができるとともに入排 気孔面樍はそれぞれ一定面樍を保つよう設計されてい る。エヤ・サイクルは10〜100の任意の膨張週期に対し て人排気の週期比を $1.0 \sim 1.9$ 範囲内に速続的に調整可 能でめる。

測定項目および測定法はつぎのとおりである。

（1）波形: 対向せる2灾のステンレス線によつて 水面の上昇下降による電気抵抗值の变化をブリッジの一 辺に入れて検出

（2）空気圧：空気室に扣将る圧力变化抵抗線式圧 力変換器にて検出

（3）ベッドの運動

a、ベッドのふくらみ度，乙まり度すなわちべッドの 密度変化一一回転円筒々粉体の外部摩擦の変化を抵抗線 式トルクメータにて检出

b.ベッドの運動方向の钼察——細長い円筒と粉体の 外部摩擦の変化老抵抗線式微小重量計にて検出

c。ベッドのサスペンジョン状態の定性的観察——選 別室の水压変化老抵抗線式圧力変換器にて检出

以上の袷出值は抵抗線式動歪計, 增幅器をへてペン書 きオッシログラフに同時記録した。

な扮供試試料は粒度分布指数 $n=1.5$, 粒度特性值 $d^{\prime}$ $=2.2 \mathrm{~mm}$ の石炭である。

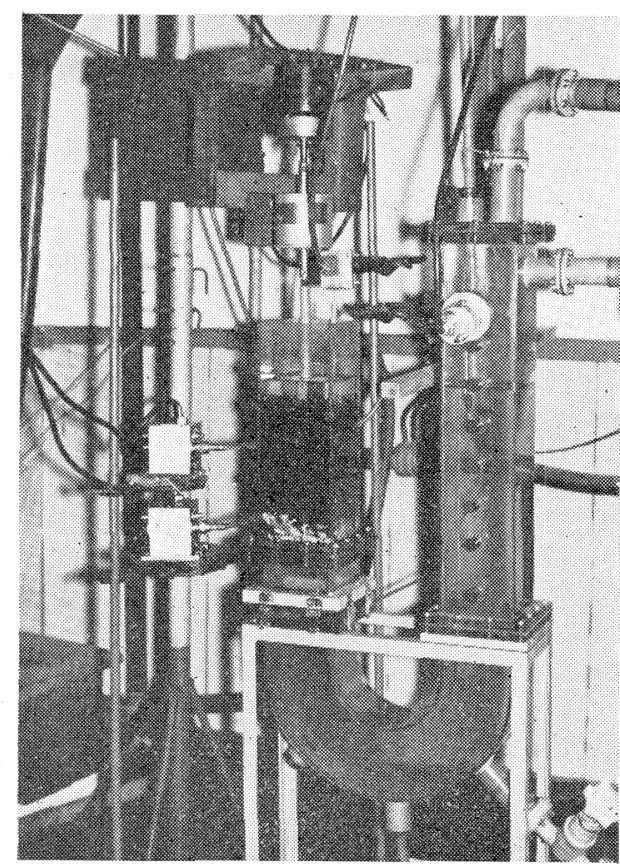

第 1 図䒠臨装置 


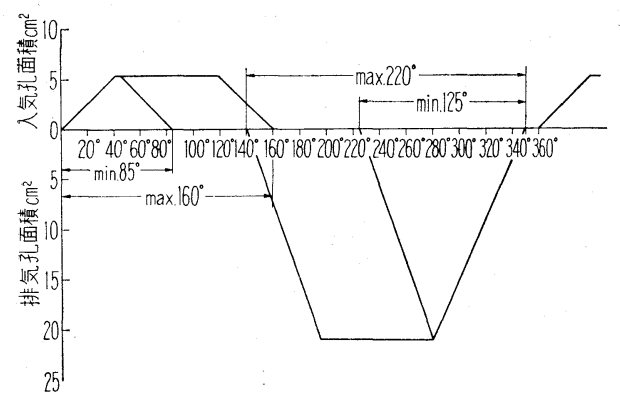

第 2 図 エヤ・バルブのポートダイヤグラム

\section{3. 実験結果と考察}

ベッドの締りの強さ, 締りと水の運動の位相羑,などジ グ・サイクルによつて, 微妙な変化を示すが，第 3 図に40 cycle $/ \mathrm{min}$, 入期週期 $110^{\circ}$, 膨張週期 $30^{\circ}$, 排気週期 $210^{\circ}$, 王縮週期 $10^{\circ}$ のエヤ・サイクル, 空気厈 $0.08 \mathrm{~kg} / \mathrm{cm}^{2}$, 網下補給水 0 の場合の測定記録を示す。

各曲線を総合観察するとベッドを構成する粒子群の運 動状態がかなり明瞭に推察できる。ベッドの密度変化を 示す曲線 $\mathrm{C}$ は水流が下降を始めて (曲線 $\mathrm{F}$ ) 約 0.2 秒後 には流動状態にあるベッドは全体的に沈降緊縮に向い, 0.9 秒後には締りは最大になることを示している。この 状況は水圧変化を示す曲線 $\mathrm{B}$ と主としてベッド下層部の 運動方向を示す曲線 $\mathrm{E}$ におる一様な下降線によつても 確認される。しかしベッド上層部の運動方向を示す曲線 $\mathrm{D}$ においては下向きの力を受ける時期は下層部より約 0.3 秒幄れて扣り, 上層部の沈降が緩慢であることを示 5。

最犬の締りに達したベッドは間もなく緩み始め, 約

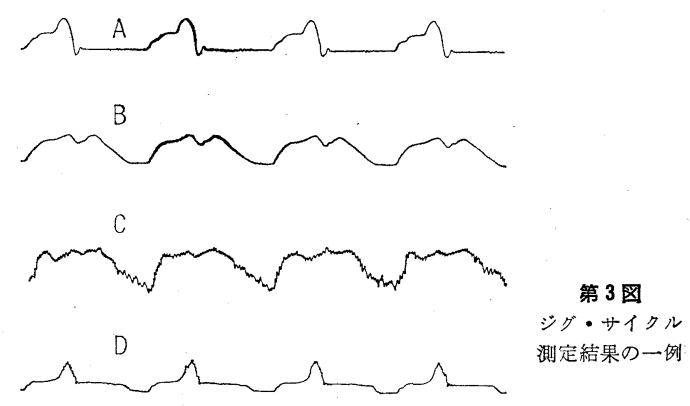

E
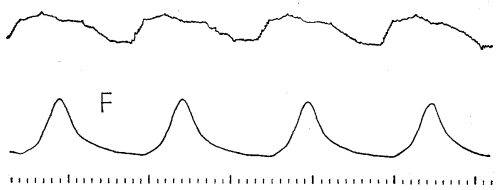

1.5 秒後水が上昇に移るころには締りはかなり弱なる (曲線 $\mathrm{C}, \mathrm{D}, \mathrm{E}$ )。この現象は予想されさかつたことであ り，その理由については検討中である。水が上昇開始後 間もなくベッド下層部は上昇し始め, 約 0.2 秒にはベッ ドが流動状態に大つたことを示すピークが現われる（曲

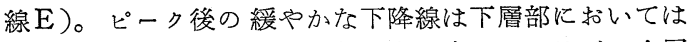
ベッドの流動化のため上向きの力を失つているが，上層 部がな扣上昇途中にあるためである（曲線D）。上層部 のベッドは下層部より $0.1 \sim 0.15$ 秒遅れて上昇し始め, 最大水位に達する $0.1 \sim 0.15$ 秒前に流動状態に入る（曲 線 D)。上下層共流動状態に大つた後は曲線 D， E はほ ぼ水平になり緩慢な沈降状態にあるものと推察される。

\section{RI 2 線源による石炭灰分の迅速測定}

\section{1. ま えがき}

石炭の生産工程あるいは燃焼系統等に扣いて，石炭の 品質を安定させ維持するためには，その変動を速やかに 検出し，その変化に対応する処置を取らねばならない。 石炭灰分の迅速測定は従来各国において種々研究されて いたが，RＩの導入により急速に発達し，信頼性のよい 装置が開発された。しかしその測定方法は大部分が後方 散乱方式であり，工業的にはいくつかの問題点が残され ている。

筆者らは前記方式と異なる 2 線源透過方式による石炭 灰分測定装置を考え，工業化を主眼として現場試験を行 なつてきたが，その実用性・問題点もある程度確められ たので，ここに報告する次第である。

な扣，この灭分測定装置の開発にあたり，基礎試験お よび工業化について早稲田大学理工学部の伏見教授なら びに黒沢助教授の適切なご指導を戴いた。

\section{2. 基 礎 試 験}

i ) 原 理

$\begin{array}{lrlll}\text { 石崖技術研究所第 } 2 \text { 研究部 } & \text { 高 } & \text { 崎 } & \text { 達 } & \text { 也(正会員) } \\ \text { 石崖技術研究所第 } 2 \text { 研究部 } & \text { ○松 } & \text { 本 } & \text { 正 } & \text { 照(正会員) }\end{array}$

$\mathrm{R} I$ 線源より放出した放射線が，物質中を通過する と, 物質を樌成する元素の固有の質量吸収係数值の差及 びその重量割合によつて, 故射線強度は照射前後によつ て変化する。その関係は R I 線源の放射線エネルギーに よつて異なる。すなわち第 1 図のようにェネルギーが $200 \mathrm{kev}$ 以上になると原子番号 $(Z)$ に関係なく, 質量吸 収係数值 $(\mu)$ は, ほぼ一定となり，100 kev 以下では Z に比例して $\mu$ が大きくなる。

つぎに $\gamma$ 線が物質中を透過すると, 放射線の強さは減 衰するが，一般に次式で表わされる。

$$
I=I_{0} e^{-\mu \rho x}
$$

$$
\begin{array}{ll}
I: \text { 物質通過後の放射線の強さ } \\
I_{0}: \text { 物質通過前の放射線の強さ } \\
\mu: \text { 物質の質量吸収系数 } \\
\rho: \text { 物質の見掛密度 } \\
x: \text { 透過する長さ }
\end{array}
$$

したがつて，二つの線源A（エネルギーの高い放射性 元素）とB（エネルギーの低い放射性元素）により，同 一物質 (石炭) を測定すると（1）式と同様につぎの式が 成り立つ。 